\title{
The Science and Art of Reviewing
}

The science and art of reviewing are rather rare.

If one were to go by the endless round of question-answers in any meeting/seminar/conference or just round table, it would appear that Indians have a very healthy appetite of offering criticism, opinions, suggestions, contrary views, sneering, or just being sarcastic!

However, if one were asked to pen them down onto to a page, as constructive criticism, there are hardly any takers! While we are raucously loud in verbal criticism, we seem to shy away from any form of formal reviewing.

Reviewing is indeed a thankless job. It rather catches one to do something that is tedious and perhaps unheeded. There is just a per functionary year end acknowledgment, buried at the end of the journal.

I grapple to find good reviewers for each new article that is submitted to the IJMPO. The journal does offer one the choice of suggesting reviewers for articles submitted.

First things first: I often find that articles are submitted in a wide variety of narrative and writing styles - often mimicking story-telling in the native tongue. One can almost predict the mother tongue of the chief author - East, West, South, or North or perhaps from the Middle East or continental Europe. Next come the grammar, syntax, and spellings. None of the omnibus of authors - some are even emeritus - seem to have read the draft or manuscript, even once, to have their names attached to the 14-odd list! It is obvious that a stenographer or typist who is unfamiliar with medical (or surgical) terminology has scripted the article. Several are verbatim versions of presentations. The novice just copy-pastes a similar looking article, merely changing the scenario and numbers. Finally, there is the serial writer - several papers, each dealing with one demographic feature, everything else remaining the same - the so-called epidemiologic study series.

I confess, students who rush to the press with a desperate deadline from the dean's office do not fare any better. They are seldom guided properly through the writing process - by the plethora of busy clinicians and busier lab personnel.

So much for the writer and the manuscript.
Let us now face the reviewer: a very rare species indeed.

The allocated reviewer seldom opens the machine-generated E-mail. Unfortunately, there are no contact numbers to prod a reminder. Since our mail service has a built-in mechanism for spamming repetitive E-mail sources, our pleas fall on deaf, if not dead, ears!

Reviewing is therefore a precious learned art. A sort of writing that endearing piece to end as a back-cover blurb that gets the paperback picked up.

My ardent plea for all manuscript submitters is as follows: please get it read by peers, if not superiors. Moreover, please suggest reviewers as you submit online - along with correct contact details. Finally, inform the unsuspecting to be on the lookout for a rather crisp E-mail requesting an early review.

The hunt for good reviewers is on - if you know any, and are willing to waste precious time to help bring articles to print, please drop me a hint. I shall grab the opportunity and implore the demi-gods called reviewers to spare their precious talent for this journal.

Perhaps, we need good workshops on manuscript writing, editing, and reviewing - at least for teachers and their hapless students.

Raghunadharao Digumarti

Director, Homi Bhabha Cancer Hospital \& Research Centre, Visakhapatnam, India E-mail: telerama@rediffmail.com

This is an open access article distributed under the terms of the Creative Commons Attribution-NonCommercial-ShareAlike 3.0 License, which allows others to remix, tweak, and build upon the work non-commercially, as long as the author is credited and the new creations are licensed under the identical terms.

\begin{tabular}{|l|l|}
\hline \multicolumn{2}{|c|}{ Access this article online } \\
\hline Quick Response Code: & Website: \\
& www.ijmpo.org \\
\cline { 2 - 2 } & DOI: \\
\hline
\end{tabular}

How to cite this article: Digumarti R. The science and art of reviewing. Indian J Med Paediatr Oncol 2017;38:1. 